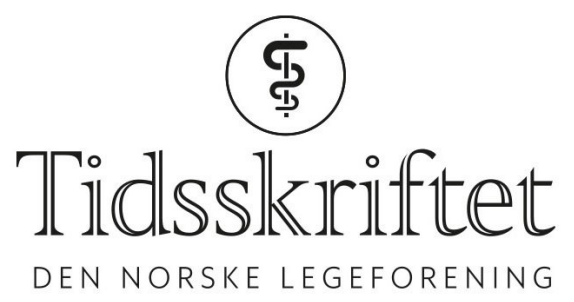

\title{
Resistens roper på revolusjon
}

KRONIKK

AMANDA HYLLAND SPJELDNAES

E-post:amanda.spjeldnas@medisin.uio.no

Amanda Hylland Spjeldnæs er tredjeårs medisinstudent og forskerlinjestudent ved Institutt for helse og samfunn, Universitetet i Oslo.

Forfatteren har fylt ut ICMJE-skjemaet og oppgir ingen interessekonflikter.

Hvis korona er en motbakke, er antibiotikaresistens en bratt fjellside. Å satse på individuell atferdsendring for å hindre resistens holder ikke. Vi trenger strukturelle tiltak som senkede forventninger til produksjonstempo, strengere antibiotikareguleringer og bekjempelse av fattigdom for å ha en sjanse.

Antibiotikaresistens er en hurtigvoksende, enorm helseutfordring og en trussel på linje med klimaforandringer og terror (1). Resistens vil medføre alvorlige sosiale, økonomiske og politiske konsekvenser og gi enorme tap av menneskeliv (2,3). Før koronapandemien var det vanskelig å forestille seg en hverdag som styres av frykt for smitte, men det er en slik fremtid vi risikerer dersom antibiotikaresistens fortsetter å utvikle seg i samme tempo som i dag. Selv om vi bruker relativt lite antibiotika i Norge, er ikke trusselen noe mindre her, for som vi har lært av korona respekterer ikke patogener landegrenser. Resistens på motsatt side av kloden trenger ikke mange mellomlandinger før den har nådd Norge. Mens det er enighet om at antibiotikaresistens krever umiddelbar handling, er det ulike meninger om hva denne handlingen bør bestå i. Dagens strategier mangler strukturelle tiltak.

\section{Individuell atferdsendring og Én helse}

Kanskje den viktigste pilaren i den internasjonale håndteringen av antibiotikaresistens er strategier som sikter mot å senke antibiotikabruk ved å endre atferden til enkeltmennesker (antibiotic stewardship) (2-4). Informasjonsspredning er en sentral intervensjon i denne tradisjonen, og tanken er at økt kunnskap om antibiotikaresistens fører til holdningsendringer hos enkeltmennesker, som gjør at helsearbeidere velger å forskrive mindre og at pasienter og bønder velger å bruke mindre antibiotika. Eksempler på atferdsrettede tiltak er kampanjer som oppfordrer til å ikke bruke antibiotika ved virusinfeksjoner, og til å vaske hendene ofte for å hindre bakteriespredning. Et annet er verdens antibiotiske bevissthetsuke i regi av Verdens helseorganisasjon.

Før koronapandemien var det vanskelig å forestille seg en hverdag som styres av frykt for smitte, men det er en slik fremtid vi risikerer dersom antibiotikaresistens fortsetter å utvikle seg i samme tempo som i dag

Individuell atferdsendring som løsning på antibiotikaresistens er et paradoks, fordi problemet er så lite individuelt. Det er for eksempel ikke som med livsstil. En dårlig livsstil $\emptyset$ ker bare risikoen for sykdom hos en selv, mens antibiotikabruk ett sted bidrar til resistens 
andre steder. Det er ikke enkeltmennesker som blir resistente mot antibiotika, men mikrobene som sprer seg i verdenssamfunnet. Flere internasjonale helsefora har trukket frem Én helse (One Health) som en strategi som kan brukes i tillegg til atferdsendring (2, 3, 5), og den medisinske antropologen Clare Chandler presenterer Én helse som en motpol til det individuelle fokuset i dagens resistensarbeid (6). Denne strategien innebærer at antibiotikabruk ikke kan forstås gjennom forbruk hos mennesker alene, men gjennom et komplekst samspill mellom mennesker, dyr og miljø. Én helse vektlegger intersektorielt samarbeid mellom blant annet veterinærer, leger, matvareprodusenter og miljøforkjempere for å finne en samlet strategi for konservering av antibiotika. Selv om Én helse i teorien kan inkludere strukturelle årsaker til resistens, er det forskere som peker på at denne strategien i praksis ofte vektlegger de biologiske og $\varnothing$ kologiske mekanismene for resistensspredning, slik at de strukturelle faktorene neglisjeres (7).

Flere reagerer på å bruke individuell atferdsendring som ledende strategi for å håndtere resistens (4, 6-11). Det finnes for eksempel studier fra lav- og mellominntektsland som viser at helsearbeidere har svært gode kunnskaper om antibiotikaresistens, men likevel forskriver mer enn de vet at de burde (8). Dette tyder på at $ø$ kt kunnskap ikke nødvendigvis fører til endret antibiotikabruk, og flere forskere peker på at de dokumenterte effektene av tiltak rettet mot individuell atferdsendring er tvilsomme (11). Atferdsendring er også problematisk ved at det i tråd med en liberalistisk tankegang pålegger individet ansvaret for å bruke mindre antibiotika. Premisset for atferdsendring er at enkeltmennesker har muligheten til å velge å bruke mindre antibiotika, men for mange er legemiddelet en del av hverdagen som de ikke kan velge bort.

\section{Antibiotika som infrastruktur}

Antibiotikabruk må forstås ut fra sosiale, kulturelle, økonomiske, materielle og strukturelle faktorer (4, 6-11). Resistens er ofte ikke en konsekvens av enkeltmenneskers irrasjonelle valg, men et symptom på strukturelle forhold. Vissheten om at antibiotika finnes som effektiv kur mot bakterieinfeksjoner, gjør at vi kan leve i et samfunn som ikke tar høyde for at disse infeksjonene kan sette oss ut av spill. Antibiotika er en byggestein i systemer som går langt utover individets ansvar, og Chandlers beskrivelse av antibiotika som infrastruktur kan hjelpe oss til å tenke nytt om resistens (6).

Å forstå antibiotika metaforisk som infrastruktur er krevende, fordi det innebærer å legge merke til måtene antibiotikabruk tas for gitt. Kanskje kan antibiotika som infrastruktur sammenlignes med en tsunami. I Oslo tyder geologien på at en flodbølge ikke vil skje, og vi kan bygge infrastruktur som bygninger, kloakksystemer, nødetater og transport som ikke trenger å tåle en flodbølge. I Japan tilsier derimot geologien at en tsunami kan komme, og der bør infrastrukturen for eksempel innebære avanserte varslingssystemer, bygninger som er konstruert for å ikke rase, beskyttelsesvegger i havet og planer for rask evakuering av innbyggere i utsatte områder. Ettersom vi har global tilgang på effektive antibiotika, kan vi konstruere samfunn som om bakterieinfeksjoner omtrent ikke eksisterer, på samme måte som at vi kan planlegge infrastruktur i Oslo som om en tsunami ikke vil skje. Sykehus kan ha en relativt liten infeksjonsavdeling og gjennomføre behandlinger som kirurgi, cytostatika og transplantasjoner uten høy infeksjonsrisiko. Myndighetene kan godta bakterier i drikkevannet. Mennesker kan bo tett med dårlige hygieniske forhold og ha ubeskyttet sex uten å være syke. Arbeidsgivere kan forvente at de ansatte ikke får sykefravær pga. bakterieinfeksjoner. Fastleger kan se 50 pasienter daglig, fordi hvis de raskt deler ut en bredspektret antibiotikakur til halvparten blir disse pasientene fornøyde, og mange av dem også friske. Bønder kan sette hundrevis av griser i samme innhegning uten å være redde for spredning av bakterier, og i noen land bruker bønder antibiotika som vekstfremmende kosttilskudd for å produsere større og mer kostbare kjøttstykker.

Individuell atferdsendring som løsning på antibiotikaresistens er et paradoks, fordi problemet er så lite individuelt 
Antibiotika muliggjør grunnleggende verdier i den moderne verden, nemlig standardisering, modernisering, urbanisering og globalisering (6). Antibiotika har gjort at det stilles unaturlige krav til tempo. Mennesker og dyr blir svært pålitelig arbeidskraft, ettersom vi sjeldnere trenger å være syke og borte fra jobb når vi har antibiotika som quick fix (10). Det bidrar til en generell standardisering og effektivisering i samfunnet, og videre til en mer forutsigbar økonomisk vekst. Forutsigbarheten og det høye tempoet bidrar til en modernisering ved at utvikling skjer raskere. Samtidig gjør antibiotika at vi kan konsentrere arbeidskraften og bo i overbefolkede byer selv om sanitærforholdene ikke tåler belastningen, for smitte kureres effektivt. Vi kan også reise kloden rundt uten frykt for å bli smittet av eller for å introdusere nye bakterier til andre samfunn, fordi sykdommene uansett raskt kan behandles.

Hvis antibiotika er infrastruktur, vil vi kanskje ikke merke resistenskrisen før det er for sent. Først når resistens er svært utbredt, vil infrastrukturen rakne. Hva vil skje om (eller når) antibiotika forsvinner? Infeksjonsavdelingene på sykehus blir overfylte, flere pasienter får infeksjonskomplikasjoner etter kirurgi og flere flyktninger sliter med kroniske bakterieinfeksjoner fra urent drikkevann. Antall sykmeldinger for enkle infeksjoner som urinveisinfeksjon stiger, og produktiviteten synker. Fastlegekøer blir lengre, ungdom får uhelbredelige kjønnssykdommer, kjøttstykkene i butikkene blir mindre og færre, og det blir kanskje en generell økt engstelse for sosial kontakt og smitte, som under koronapandemien.

\section{Utjevning av global ulikhet}

Antibiotika kamuflerer fattigdom og dårlige levekår gjennom å kompensere for mye av det som ikke fungerer i samfunnet. Noen er mer avhengige av antibiotika enn andre, særlig flyktninger i fattige kår. Her er antibiotika viktigere for å holde samfunnet i gang, ettersom de strukturelle forholdene er dårligere. For eksempel er det ikke bare litt urent drikkevann av og til, men veldig urent drikkevann hele tiden. Man bor ikke bare ganske tett, men i overfylte telt. Fastleger ser ikke bare 50 pasienter på en dag, men kanskje det dobbelte. Sykehuset har ikke bare en liten infeksjonsavdeling, for det finnes ikke noe tilgjengelig sykehus. Og så videre. Å miste tilgangen på antibiotika, enten ved resistens eller ved strengere regler for bruk, vil gi langt større konsekvenser ved dårlige levekår enn ved gode. Konsekvensene kan for eksempel være en kraftig økning i sykdom og død, nedsatt produktivitet, mer økonomisk elendighet og mindre sosial mobilitet.

Hva vil skje om (eller når) antibiotika forsvinner?

Tiltak for å stoppe lidelse hos de fattige må rettes mot de komplekse og bakenforliggende årsakene til lidelsen (12). Global ulikhet og fattigdom er sentrale oppstrømsårsaker til resistens ved at de øker avhengigheten av antibiotika. Forbedrede levekår og velferd vil øke sjansene for å klare seg uten slike legemidler. Det er særlig høye forekomster av resistens i lav- og mellominntektsland (3) og i flyktningleirer (13), og det er ekstra viktig at strategier for å hindre resistens tilpasses disse kontekstene ved å rettes mot bakenforliggende strukturelle faktorer. Ikke bare for de fattiges og flyktningenes del, men også fordi resistens sprer seg raskt fra å være et lokalt problem til å være et globalt.

\section{Ny samfunnsstruktur}

For å lykkes i å begrense antibiotikaresistens trenger vi nye internasjonale strategier som tar høyde for betydningen av strukturelle forhold bak antibiotikabruk. Forståelsen av antibiotika som strukturelt betinget gjør resistensutfordringen større. Det krever langt mer politisk vilje og ressurser for å få endret samfunnets verdier og oppbygning enn for å få gjennomført atferdsrettede kampanjer om håndvask. Slike strukturelle tiltak kan være å senke forventninger til produksjonstempo, forbedre globale sanitærforhold, bekjempe fattigdom samt innføre strengere internasjonale reguleringer for antibiotika i landbruk. Utfordringen er likevel ikke umulig, og en rekke forskere fremhever tverrfaglig samarbeid 
mellom medisin og samfunnsvitenskaper som antropologi for å avdekke nye sammenhenger mellom strukturelle forhold, antibiotikabruk og resistens, som videre kan danne grunnlaget for strukturelle tiltak $(9,11,14)$. Et mulig første steg for medisinere i Norge er å ta initiativ til tverrfaglige forskningsprosjekter der man utforsker antibiotikabruk som konsekvens av strukturelle forhold.

\section{LITTERATUR:}

1. McCarthy M. Resistance to antibiotics: risks, health "catastrophe” to rank with terrorism and climate change. Independent 11.3.2013.

https://www.independent.co.uk/news/science/chief-medical-officer-dame-sally-davies-resistance-antib iotics-risks-health-catastrophe-rank-terrorism-and-climate-change-8528442.html Lest 19.3.2021.

2. World Health Organization. Global Action Plan on Antimicrobial Resistance.

https://apps.who.int/iris/bitstream/handle/10665/193736/9789241509763_eng.pdf?sequence=1 Lest 19.3.2021.

3. Laxminarayan R, Duse A, Wattal C et al. Antibiotic resistance-the need for global solutions. Lancet Infect Dis 2013; 13: 1057-98. [PubMed][CrossRef]

4. Dyar OJ, Huttner B, Schouten J et al. What is antimicrobial stewardship? Clin Microbiol Infect 2017; 23: 793-8. [PubMed][CrossRef]

5. Laxminarayan R, Van Boeckel T, Frost I et al. The Lancet Infectious Diseases Commission on antimicrobial resistance: 6 years later. Lancet Infect Dis 2020; 20: e51-6o. [PubMed][CrossRef]

6. Chandler CIR. Current accounts of antimicrobial resistance: stabilisation, individualisation and antibiotics as infrastructure. Palgrave Commun 2019; 5: 53. [PubMed][CrossRef]

7. Hinchliffe S. More than one world, more than one health: re-configuring interspecies health. Soc Sci Med 2015; 129: 28-35. [PubMed][CrossRef]

8. Pearson M, Doble A, Glogowski R et al. Antibiotic prescribing and resistance: Views from low- and middle-income prescribing and dispensing professionals. Geneve: World Health Organisation AMR Secretariat, 2018.

https://www.who.int/antimicrobial-resistance/LSHTM-Antibiotic-Prescribing-LMIC-Prescribing-and-Di spensing-2017.pdf Lest 19.3.2021.

9. Chandler C, Hutchinson E, Hutchison C. Addressing antimicrobial resistance through social theory: An anthropologically oriented report. London: London School of Hygiene \& Tropical Medicine, 2016. https://researchonline.lshtm.ac.uk/id/eprint/340050o/1/Addressing\%20Antimicrobial\%2oResistance\%2 oThrough\%2OSocial\%2oTheory\%2oGOLD\%2oVoR.pdf Lest 19.3.2021.

10. Denyer Willis L, Chandler C. Quick fix for care, productivity, hygiene and inequality: reframing the entrenched problem of antibiotic overuse. BMJ Glob Health 2019; 4: eoo159o. [PubMed][CrossRef]

11. Tompson AC, Chandler CIR. Addressing antibiotic use: insights from social science around the world. A report collated with social scientists of the Antimicrobials in Society Hub. London: London School of Hygiene and Tropical Medicine, 2021. https://researchonline.lshtm.ac.uk/id/eprint/4659562/ Lest 19.3.2021.

12. Farmer P. Pathologies of power: health, human rights, and the new war on the poor. Berkeley, CA: University of California Press, 2003.

13. Nellums LB, Thompson H, Holmes A et al. Antimicrobial resistance among migrants in Europe: a systematic review and meta-analysis. Lancet Infect Dis 2018; 18: 796-811. [PubMed][CrossRef]

14. Minssen T, Outterson K, Rogers Van Katwyk S et al. Social, cultural and economic aspects of antimicrobial resistance. Bull World Health Organ 2020; 98: 823-823A. [PubMed][CrossRef]

Publisert: 28. juni 2021. Tidsskr Nor Legeforen. DOI: 10.4045/tidsskr.21.0070

Mottatt 25.1.2021, første revisjon innsendt 12.3.2021, godkjent 19.3.2021.

(C) Tidsskrift for Den norske legeforening 2020. Lastet ned fra tidsskriftet.no 